\title{
PROBLEMATA UbOBVHWVLF
}

\section{MARGINAIS E CLANDESTINOS: OUTRAS FILOSOFIAS}

\author{
Antonio Charles Santiago Almeida ${ }^{1}$ \\ Samon Noyama ${ }^{2}$ \\ Leandro Sousa Costa ${ }^{3}$
}

A proposta de um dossiê sobre o tema "Marginais e clandestinos" tem origem nas preocupações que circundavam os debates filosóficos e políticos que ocorreram na Universidade Estadual do Paraná, no Campus de União da Vitória, nos semestres que antecederam o VII Colóquio de Filosofia da Unespar, realizado em novembro de 2014, cujo título foi "Marginais e clandestinos: outras filosofias".

Enquanto este debate ocupou as mesas, reuniões e salas de aula do curso de Filosofia da Unespar, em momento algum a discussão tomou o caminho de se desfazer ou deixar de lado a tradição filosófica do ocidente, seus problemas centrais, métodos, objetos e autores “clássicos". Havia, na verdade, uma grande preocupação com muitas questões que começavam a chamar a atenção no cenário de nosso país, sobretudo do ponto de vista da cultura e da política, para as quais não se encontrava exatamente uma abordagem oferecida pela história majoritária da filosofia ocidental moderna que contemplasse com algum grau de satisfação. Vivíamos, efetivamente, a insurgência das questões de gênero, das minorias, dos colonizados, das periferias, da exclusão social e dos desdobramentos que os tempos de crise anunciavam já naquele fim de 2014.

Diante da necessidade de pensarmos essas questões e do reconhecimento de nossa incapacidade de levarmos, sozinhos, esta discussão a um patamar formativo e investigativo à altura da importância desses temas para o mundo contemporâneo, decidimos realizar um

\footnotetext{
${ }^{1}$ Doutor em Educação e professor adjunto da Universidade Estadual do Paraná, Campus de União da Vitória e professor do Programa de Filosofia - PRO-FILO. sandiabo@yahoo.com.br

${ }^{2}$ Doutor em Filosofia. Professor adjunto do Curso de Filosofia da Universidade Estadual do Paraná campus de União da Vitória. Professor efetivo do Programa de Mestrado Profissional em Filosofia (PROF-FILO). Membro do KHORA - Laboratório de filosofias da alteridade (UFRJ). Email: snoyama@gmail.com

${ }^{3}$ Doutorando em Filosofia pela Pontifícia Universidade Católica do Paraná e Professor do curso de Filosofia da Universidade Estadual do Paraná. E-mail: leandro kallas@,hotmail.com
} 
encontro que pudesse dar o primeiro passo na direção desse enfrentamento que, se há quatro anos parecia importante, hoje é imprescindível. Não se pode mais ignorar a relevância dos temas que a filosofia se acostumou a ignorar e que, a academia como um todo, se furtou a pensar sob bases científicas e com fundamentos específicos reconhecidamente legítimos.

Foram convidados os professores Rafael Haddock-Lobo, Susana de Castro Amaral Vieira, Francisco Bocca, Maria Adriana Capello e Luciano Nascimento. As palestras e oficinas foram pensadas a partir de dois eixos, a saber: os filósofos e pensadores que não desfrutaram ou sequer foram reconhecidos no ambiente acadêmico pelos seus trabalhos e obras, e os temas que a filosofia deliberou por deixar à margem e na clandestinidade pelos mais diversos motivos e escusas, mas que, ao fim e ao cabo, nunca gozaram de prestígio nas investigações e nos debates filosóficos de destaque.

Passados quatro anos da ocorrência do evento, é preciso dizer que encontrarmos um cenário muito diferente daquele, principalmente porque os embates políticos pelos quatro cantos do nosso país, nem sempre notados pela qualidade dos argumentos e das discussões, acabaram por contribuir para a visibilidade de questões que, hoje, mesmo a contragosto, não podem ser ignoradas. Os textos produzidos para o evento têm outra dimensão e podem contribuir de forma muito mais efetiva neste momento. A crise generalizada que vivemos hoje no Brasil, que se prolifera nas entranhas de nossas instituições e que tem reconhecimento junto às esferas mais cotidianas e simples do nosso exercício diário de cidadania, clama por muitos debates, discussões e momentos oportunidades para enriquecer nossa formação e nossas condições de enfrentar as questões que nos afetam.

Por isso buscamos recuperar toda essa contribuição e oferecer aos leitores interessados da filosofia uma oportunidade para estabelecer diálogos e semear as discussões das quais a filosofia não deveria ter negligenciado. Somados aos trabalhos dos convidados para o evento, trazemos as reflexões dos docentes da Unespar e outros professores que, de uma forma ou de outra, cruzam este caminho e com ele vêem a urgência da manifestação.

Por fim, gostaríamos de fazer um agradecimento especial a todo o pessoal da Revista Problemata na pessoa do professor Edmilson Azevedo, pela generosidade em acolher a nossa proposta e ceder este espaço para publicação do nosso dossiê e por fim, e não menos importante, ao professor Leandro Sardeiro, por intermediar o nosso contato. 